DOI: $10.21802 / \operatorname{artm} .2021 .2 .18 .26$.

UDC $616-71+615.825+616.127-005.8+616.12-008.46$

\title{
CLINICAL FEATURES OF THE REHABILITATION PERIOD AFTER THE PREVIOS MYOCARDIAL INFARCTION AND DECOMPENSATED HEART FAILURE WITH ACCOUNT OF CARDIOVASCULAR RISK FACTORS
}

\author{
I.P. Vakaliuk, K.V. Levandovska, N.B. Tymochko \\ Ivano-Frankivsk National Medical University, Department of internal medicine №2 and nursing, \\ Ivano-Frankivsk, Ukraine, \\ ORCID ID: 0000-0002-4430-6816, \\ ORCID ID: 0000-0003-3259-7940, \\ ORCID ID: 0000-0002-5319-5468, \\ e-mail: levandovska87@ukr.net
}

Abstract. Cardiovascular diseases (CVD) are known to account for one-third of all deaths worldwide. According to the American Heart Association, $18 \%$ of men and 35\% of women with prior acute myocardial infarction (AMI) developed recurrent AMI within 6 years after initial MI; $22 \%$ of men and 46\% of women were disabled due to the development of chronic heart failure (CHF).

The purpose: to analyse clinical features of recovering period after myocardial infarction taking into account cardiovascular risk factors.

Materials and methods. 175 persons with myocardial infarction and related risk factors were examined. Study groups were homogenous by age, gender, disease severity, clinical signs of decompensation, that served as a basis for inclusion of the patients in the research.

All patients underwent the general-clinical examination (pain syndrome analysis, medical history, objective signs), clinical and instrumental (electrocardiography, echocardioscopy, 6-minute walk test, in a quiet 30-50-m long hospital corridor in the morning) and laboratory tests (lipidogram, leptin level). Study groups were homogenous by age, gender, disease severity, duration of the post-infarction period, clinical signs of decompensation. All patients were divided into groups according to the presence of risk factors: group 1 of MI with HF (74 patients), group $2-\mathrm{MI}$ with AH (76 patients), group 3 - MI and obesity (72 patients); group 4 consisted of patients with all risk factors (78 patients) together. The obtained results were statistically processed on the personal computer by means of an advanced analytics software package STATISTICA-7 and a statistical software package "Microsoft-Excel" using the statistical variation analysis.

Results. The most important cardiovascular risk factors, which aggravate the post infarction period are age, arterial hypertension, diabetes mellitus, heart failure, congenital and acquired valvular defects, obesity. In patients with heart failure, recovering period is characterized by stabile heartbeat, reduced exercise tolerance combined with progressing dilatation of left ventricular chambers in $83.78 \%$ of patients. Patients with arterial hypertension have stable anginal pain syndrome and reduced exercise tolerance ( $89.47 \%$ of cases). In obese patients, consistent fatigue, general weakness, dyspnoea, high levels of total cholesterol and leptin in blood serum (81.94\% of patients) are mostly observed. In patients with combined heart failure, arterial hypertension, obesity, the recovery period clinics after myocardial infarction is characterized by significantly reduce of exercise tolerance $(92.30 \%$ of patients). Shortness of breath, which was accompanied by heart palpitations, was prevalent in the group of patients with HF (89.1\%) and was the least manifested in the group of patients with obesity (52.7\%).

Conclusions. Changes in cardiac hemodynamics in patients who had undergone the myocardial infarction with concomitant heart failure and with a combination of risk factors were accompanied by the eccentric hypertrophy onset, characterized by a combination of the left venricle cavities dilation with hypertrophy of its walls and the decreased contractility. The presence of decompensated heart failure significantly degrades the performance of six-minute walk test.

Keywords: myocardial infarction, decompensated heart failure, risk factors, recovery period.

Introduction. Cardiovascular diseases (CVD) are known to account for one-third of all deaths worldwide [1]. According to the American Heart Association, $18 \%$ of men and $35 \%$ of women with prior acute myocardial infarction (AMI) developed recurrent AMI within 6 years after initial MI; $22 \%$ of men and $46 \%$ of women were disabled due to the development of chronic heart failure (CHF). Due to the improvement of the methods for AMI diagnosis and treatment, the mortality rate has significantly decreased. This contributed to the increase in the number of the patients who survived initial and recurrent episodes; thus, the number of the patients with the signs of $\mathrm{CHF}$ and its decompensation increased as well [2]. CHF is a syndrome resulting from the inability of the heart to provide enough blood for normal metabolism on the background of normal venous outflow and cardiac filling pressure [4]. 
Early stratification of risk lies in the choice of medical tactics. It is known that the modern approach to the treatment of patients with MI involves the obligatory distribution of patients according to the risk of adverse events occurrence in them - a new (repeated) MI or death. A recent study [3] confirmed that a number of lifestylerelated risk factors such as tobacco smoking, lack of physical activity, inappropriate nutrition, obesity, along with others, often resulting from previous arterial hypertension ( $\mathrm{AH})$, type 2 diabetes mellitus (DM), dyslipidemia and heart failure (HF) can be modified. Adequate detection and elimination of modified risk factors, taking into account the unmodified ones, stratification of risk and individualization of therapy along with the definition of remote prediction for a particular patient will significantly improve the efficiency of all treatment and prevention measures [5].

For many years, it was recommended to avoid physical activity after a MI; nowadays, it is a consensus that exercise training (ET) should be part of cardiac rehabilitation programs. There is increasing evidence to support that with adequate prescribing and supervising of ET after MI, can prevent future complications and increase the quality of life and longevity of infarcted patients [6].

Rationale for the research. Patients who have experienced a MI have an increased risk of sudden cardiac death. The mortality risk associated with a reduced left ventricle ejection fraction (LVEF) after MI has long been recognized [7]. In patients with low risk of events after an acute myocardial infarction, the actual policy is to offer simple consultations without formal exercise programs [8]. However, in the current era of limited funding, it has been proposed that patients with normal left ventricular ejection fraction in the early postAMI phase, who are at relatively low risk of subsequent events, might be offered more affordable, simple lifestyle counselling instead of costlier programs that include physical training [9]. One of the most important predictors of long-term evolution after an AMI is represented by the left LV remodeling. Postinfarction LV represents a maladaptive and dynamic process that results from the complex interaction between the size of the infarcted area, genetic predisposition and inflammation, in which systemic inflammation plays a crucial role [10].

The purpose of the present research was to analyze the clinical features of the recovery period after myocardial infarction, taking into account the cardiovascular risk factors.

Materials and methods. The total of 175 persons with MI and related risk factors were examined (there were I, II and III stages and I and II stages of obesity), aged 40 to 70 years. Patients with MI were included into the research from the 24th-28th days after the acute MI period.

All patients underwent the general-clinical examination (pain syndrome analysis, medical history, objective signs), clinical and instrumental (electrocardiography, echocardioscopy, 6-minute walk test) and laboratory tests (lipidogram, leptin level).

All patients were divided into groups according to the presence of risk factors: group 1 of MI with HF (74 patients), group 2 - MI with AH (76 patients), group 3 MI and obesity (72 patients); group 4 consisted of patients with all risk factors (78 patients) together. We also examined 30 healthy persons of the same age and sex to determine the normal values of the studied parameters.

The average age of patients with MI was $(51.96$ \pm 5.7 ) years. Of these, patients with HF were $16.66 \%$ (50) men and $8.0 \%$ (24) women; $\mathrm{AH}-10.33 \%$ (31) men and $15.0 \%$ (45) women; obese patients made $17.33 \%$ (52) men and $6.66 \%$ (20) women; patients with various risk factors made $15 \%(45)$ men and $11.0 \%$ (33) women.

In 57 examined patients $(19.0 \%)$, a repeated MI was diagnosed. Characteristics of MI localization and its complications in the acute period are presented in table 1.

Table 1

Characteristics of MI localization and its acute period complications in the examined patients

\begin{tabular}{|c|c|c|c|c|}
\hline MI localization & $\begin{array}{c}\text { HF } \\
(\mathrm{n}=74)\end{array}$ & $\begin{array}{c}\text { AH } \\
(\mathrm{n}=76)\end{array}$ & Obesity $(\mathrm{n}=72)$ & $\begin{array}{c}\text { Risk factors combined } \\
(\mathrm{n}=78)\end{array}$ \\
\hline \multicolumn{5}{|c|}{ MI localization } \\
\hline Anteroseptal & $12,16 \%(9)$ & $14,47 \%(11)$ & $11,11 \%(8)$ & $16,66 \%(13)$ \\
\hline Anteroapical & $9,45 \%(7)$ & $13,15 \%(10)$ & $8,33 \%(6)$ & $14,10 \%(11)$ \\
\hline Lateral & $5,40 \%(4)$ & $3,94 \%(3)$ & $4,16 \%(3)$ & $2,56 \%(2)$ \\
\hline Inferior & $8,10 \%(6)$ & $5,26 \%(4)$ & $6,94 \%(5)$ & $5,12 \%(4)$ \\
\hline Posterobasal & $2,70 \%(2)$ & $1,31 \%(1)$ & $6,94 \%(5)$ & $1,28 \%(1)$ \\
\hline Circumferential & $2,70 \%(2)$ & $1,31 \%(1)$ & $4,16 \%(3)$ & $1,28 \%(1)$ \\
\hline \multicolumn{5}{|c|}{ MI acute period complications } \\
\hline Cardiogenic shock & $6,75 \%(5)$ & $3,94 \%(3)$ & $2,77 \%(2)$ & $7,69 \%(6)$ \\
\hline Cardiac rhythm conduction & $6,75 \%(5)$ & $10,52 \%(8)$ & $8,33 \%(6)$ & $8,97 \%(7)$ \\
\hline disorder & \multicolumn{5}{|c|}{$10,52 \%(8)$} & $5,55 \%(4)$ & $2,56 \%(2)$ \\
\hline Cardiac asthma & $10,81 \%(8)$ & $1,31 \%(1)$ & $0,00 \%(0)$ & \\
\hline Reflective collapse & $2,70 \%(2)$ & 1. Indicated percentage to the patients in the group. & \\
\hline Note: & 2. Absolute numbers are given in brackets.
\end{tabular}

Statistical processing of the study materials was carried out using the methods of biostatistics with the STATISTICA 8.0 package (StatsoftInc., USA).
Research results and their discussion. Analyzing the nature of the retrosternal pain, we noted that patients who had suffered the MI with a combination of 
factors had not only a more pronounced pain $92.3 \%$, but also a significant incidence of other clinical signs, including general weakness $(80.7 \%)$, rapid fatigue $(79.4 \%)$, excessive sweating $(85.8 \%)$, which already indicates a more complicated course of the recovery period after the MI compared to the effects of individual risk factors.

The highest SBP and DBP were found in patients with concomitant hypertension (166.00 $\pm 1.38 /$ $99.00 \pm 0.92 \mathrm{~mm} \mathrm{Hg}$ ), high blood pressure in the group of patients with a combination of risk factors for cardiovascular events $(161.00 \pm 1.20 / 97.00 \pm 0.85)$.

Such changes are recorded on the background of tachycardia, which was observed in all groups of patients. Shortness of breath, which was accompanied by heart palpitations, was prevalent in the group of patients with HF $(89.1 \%)$ and was the least manifested in the group of patients with obesity $(52.7 \%)$.
If these signs are considered as HF manifestations, then it corresponded to the III FC (NYHA classification) by the severity degree.

Along with this, shortness of breath and heartbeat can be considered the equivalent of coronary heart disease and also a consequence of myocardial infarction and can be regarded as signs of the coronary flow deterioration.

Analyzing the results of a six-minute walk test, it was found that the lowest exercise tolerance was observed in the group of patients with a combination of risk factors, as evidenced by the lowest rate at which the patients in this group overcame the smallest distance for $(3.56 \pm 0.04)$ min., the greatest distance with the highest speed was overcome by patients with concomitant obesity (table 2).

Table 2

Indices of the 6 minute-walk test in patients after the MI with account of the risk factors $(M \pm m)$

\begin{tabular}{|c|c|c|c|c|c|}
\hline \multirow{2}{*}{$\begin{array}{l}\text { Index, } \\
\text { units of measure }\end{array}$} & \multirow{2}{*}{$\begin{array}{l}\text { Healthy persons } \\
\qquad(n=30)\end{array}$} & \multicolumn{4}{|c|}{ Patients after the MI } \\
\hline & & $\mathrm{HF}(\mathrm{n}=74)$ & $\begin{array}{c}\mathrm{AH} \\
(\mathrm{n}=76)\end{array}$ & Obesity $(n=72)$ & $\begin{array}{c}\text { Risk factors } \\
\text { combined }(n=78)\end{array}$ \\
\hline Distance, $\mathrm{m}$ & $450,67 \pm 3,56$ & $\begin{array}{c}228,75 \pm 2,21 \\
\mathrm{p}_{1^{*}}\end{array}$ & $289,42 \pm 3,23 ; \mathrm{p}_{1} \mathrm{p}_{2 *}$ & $\begin{array}{c}358,16 \pm 2,35 ; \mathrm{p}_{1} \\
\mathrm{p}_{2^{*}}\end{array}$ & $\begin{array}{c}198,11 \pm 2,26 \\
\mathrm{p}_{1} \mathrm{p}_{2} \mathrm{p}_{3} \mathrm{p}_{4} *\end{array}$ \\
\hline Capacity, W & $5608,92 \pm 36,74$ & $\begin{array}{l}3750,25 \pm \\
40,46 ; \mathrm{p}_{1 *}\end{array}$ & $\begin{array}{c}5310,16 \pm 37,66 \mathrm{p}_{1} \\
\mathrm{p}_{2^{*}}\end{array}$ & $\begin{array}{c}6370,50 \pm 42,12 \\
\mathrm{p}_{1} \mathrm{p}_{2^{*}}\end{array}$ & $\begin{array}{c}4451,91 \pm 41,47 \\
\mathrm{p}_{1} \mathrm{p}_{2} \mathrm{p}_{3} \mathrm{p}_{4}\end{array}$ \\
\hline $\begin{array}{c}\text { Heart rate before } \\
\text { load, BPM }\end{array}$ & $76,25 \pm 1,23$ & $\begin{array}{c}89,43 \pm 1,19 \\
\mathrm{p}_{1 *}\end{array}$ & $\begin{array}{c}98,79 \pm 1,34 \\
\mathrm{p}_{1} \mathrm{p}_{2^{*}}\end{array}$ & $\begin{array}{c}82,42 \pm 1,20 \\
\mathrm{p}_{1} \mathrm{p}_{2} *\end{array}$ & $\begin{array}{l}99,00 \pm 1,29 \\
\mathrm{p}_{1} \mathrm{p}_{2} \mathrm{p}_{3} \mathrm{p}_{4 *}\end{array}$ \\
\hline $\begin{array}{l}\text { Heart rate } \\
\text { after load, } \\
\text { BPM }\end{array}$ & $88,34 \pm 1,56$ & $\begin{array}{c}95,33 \pm 1,45 \\
\mathrm{p}_{1} *\end{array}$ & $105,64 \pm 2,06 ; \mathrm{p}_{1} \mathrm{p}_{2}$ & $\begin{array}{l}98,71 \pm 1,60 \\
\mathrm{p}_{1 *}, \mathrm{P}_{2^{* *}} \mathrm{p}_{3^{*}}\end{array}$ & $\begin{array}{c}122,66 \pm 1,81 \\
\mathrm{p}_{1} \mathrm{p}_{2} \mathrm{p}_{3} \mathrm{p}_{4 *}\end{array}$ \\
\hline $\begin{array}{c}\text { Time of } \\
\text { performing, min. }\end{array}$ & $5,99 \pm 0,01$ & $\begin{array}{c}5,52 \pm 0,05 \\
\mathrm{p}_{1 *}\end{array}$ & $\begin{array}{c}4,20 \pm 0,03 \\
\mathrm{p}_{1} \mathrm{p}_{2} *\end{array}$ & $\begin{array}{c}5,44 \pm 0,04 \\
\mathrm{p}_{1} \mathrm{p}_{2} *\end{array}$ & $\begin{array}{l}3,56 \pm 0,04 \\
\mathrm{p}_{1} \mathrm{p}_{2} \mathrm{p}_{3} \mathrm{p}_{4 *}\end{array}$ \\
\hline $\begin{array}{c}\text { SBP } \\
\text { before load, } \\
\text { mm Hg }\end{array}$ & $126,00 \pm 2,31$ & $\begin{array}{c}140,00 \pm 0,87 \\
\mathrm{p}_{1}\end{array}$ & $\begin{array}{c}163,00 \pm 0,92 ; \mathrm{p}_{1} \mathrm{p}_{2} \\
*\end{array}$ & $\begin{array}{c}152,00 \pm 1,01 \\
\mathrm{p}_{1} \mathrm{p}_{2} \mathrm{p}_{3 *}\end{array}$ & $\begin{array}{r}162,00 \pm 0,96 ; \\
\mathrm{p}_{1} \mathrm{p}_{2} \mathrm{p}_{3} \mathrm{p}_{4 *}\end{array}$ \\
\hline $\begin{array}{c}\text { DBP } \\
\text { after load, } \\
\mathrm{mm} \mathrm{Hg}\end{array}$ & $142,00 \pm 1,25$ & $159,00 \pm 0,78 ; p_{1} *$ & $\begin{array}{c}182,00 \pm 0,87 ; \mathrm{p}_{1} \mathrm{p}_{2} \\
*\end{array}$ & $\begin{array}{c}161,33 \pm 0,90 \mathrm{p}_{1^{*}} \\
\mathrm{p}_{2^{* *}} \mathrm{p}_{3^{*}}\end{array}$ & $\begin{array}{c}176,00 \pm 0,78 \\
\mathrm{p}_{1} \mathrm{p}_{2} \mathrm{p}_{3} \mathrm{p}_{4 *}\end{array}$ \\
\hline
\end{tabular}

Note: $\quad$ Reliability of comparison indices difference: $p_{1}$ - with healthy persons; $p_{2}-$ with HF patients; $p_{3}$ with hypertension patients; $\mathrm{p}_{4}$ - with obese patients, $*<0.05$. $* *>0.05$

The greatest work with the highest capacity was performed by patients with obesity, and the smallest values of these indices were found in the group of patients with concomitant HF, which indicates the greatest working capacity decrease in the patients of this group. In terms of heart rate, the highest physical activity was observed in the group of patients with a risk factors combination, and the lowest - in the group of patients with obesity; after the test, the lowest figures were observed in the group of patients with concomitant HF, and the highest rates - in the general group of patients $(p<0.05)$.

In the analysis of ECG-signs of myocardial ischemia, it was found that the largest depression of the ST V4-5 segment was observed in the group of patients with a combination of risk factors, and the smallest of its manifestations during the exercise test was observed in the group of patients with concomitant hypertension.
The functional state of patients at the described stage of the remedial treatment and rehabilitation was characterized by the following hemodynamics indices.

Patients with a combination of risk factors and concomitant conditions differed from those of other groups by higher rates of both metric and volume indices of the left ventricle (LV), in particular, the end-diastolic volume $(\mathrm{EDV})$ in such patients was $(192.96 \pm 2$. 17) $\mathrm{ml}$ end-systolic volume (ESV) was $(149.13 \pm 2.03) \mathrm{ml}$ with the end-diastolic (EDS) and the end-systolic size (ESS) making $(5.96 \pm 0.03) \mathrm{cm}(4.83 \pm 0.05) \mathrm{cm}$ respectively, indicating significant post-infarction LV dilatation. These changes were also clearly expressed in the group of patients with concomitant HF.

The thickness of the left ventricle posterior wall (LVPW) and the interventricular septum (IVS) in the group of patients with HF did not differ significantly from that of healthy persons, which, however, may on the contrary indicate a refinement of the LV walls. This can 
not be said about patients with a combination of risk factors, in whom the thickness of LVPW was $(1.50 \pm$ $0.01) \mathrm{cm}$, the IVS thickness $-(1.16 \pm 0.01) \mathrm{cm}$, which is due to LV hypertrophy, which has grown as a result of both $\mathrm{HF}$ and $\mathrm{AH}$, and in combination with dilatation, $\mathrm{LV}$ affects the ejection fraction (EF) index in this group of patients, tolerance to physical loads and their further working capacity. Regarding the EF indices, the greatest value of reducing the $\mathrm{LV}$ contractility was also observed in patients with a combination of risk factors and HF, somewhat higher were those in obese and hypertensive patients.

Significantly lower was the dilation of LV cavities in obese patients, where the EDV was (149.66 \pm 1.80) $\mathrm{ml}$; ESV - $(81.00 \pm 2.00) \mathrm{ml},(\mathrm{p}<0.05)$; EDS and ESS - $(5.76 \pm 0.05) \mathrm{cm},(4.33 \pm 0.04) \mathrm{cm}$, respectively, against the background of pronounced concentric LV hypertrophy.

In patients with hypertension, who had the MI, the $\mathrm{LV}$ volume was increased in the presence of an increased LVPW thickness $(1.36 \pm 0.01) \mathrm{cm}$ and IVS $(1.36$ $\pm 0.02) \mathrm{cm}$. The EDV of these patients was $(161,06 \pm$ 1.47) $\mathrm{ml}$, which significantly differed from healthy persons - $(115.00 \pm 2.05) \mathrm{ml},(\mathrm{p}<0.05)$.

The left atrium (LA) diameter was increased in all groups of patients, exceeding the value $(2.94 \pm 0.06)$ $\mathrm{cm}$ in healthy persons, which may indirectly indicate a disruption of the diastolic LV filling, regardless of the EF value. However, the highest rate was in patients with a combination of risk factors $-(4.60 \pm 0.06) \mathrm{cm},(\mathrm{p}<0.05)$.

At the same time, the hemodynamic characteristics in the examined groups of patients with MI indicated signs of cavity dilation and decreased LV contractility in the background of its hypertrophy, all of the above values being higher than the normal indices, and therefore, can indirectly indicate the presence of diastolic LV dysfunction in patients of all groups.

The lipid blood spectrum had the highest blood serum total cholesterol (TC) level in the general group of patients $(6.10 \pm 0.11) \mathrm{mmol} / 1$, in the group of obese patients - $(6.10 \pm 0.11) \mathrm{mmol} / 1(\mathrm{p}<0.05)$. In other groups of patients, the concentration of cholesterol was close to that of healthy persons. Hypertriglyceridemia was established in a group of patients with a combination of risk factors and in patients who had the MI with concomitant AH. The growth in the beta-lipoproteins content was observed in all groups of patients, but the highest level was noted in patients with a combination of risk factors $(7761,27 \pm 83,21) \mathrm{mmol} / 1$, and the lowest one in patients with concomitant HF.

Assessing the leptin level permitted to establish its highest levels in patients with MI with a combination of risk factors $(13,98 \pm 0,19, \mathrm{p}<0,05)$ and obesity $(17,23$ $\pm 0,31, \mathrm{p}<0,05)$ and some lower in patients with concomitant HF $(7.32 \pm 0.12, \mathrm{p}<0.05)$ and hypertension $(6.54 \pm$ $0.12, p<0.05)$, which reflects the degree of myocardial tissues injury and may be a predictor of cardiovascular complications.

Conclusions. Thus, the most characteristic complaints of patients with acute MI at the stage of scarring were retrosternal pain, rapid fatigue and general weakness. Shortness of breath is most often observed in patients with concomitant HF and a combination of risk factors and concomitant conditions; headache most commonly occurred in MI patients with concomitant hypertension, and in patients with a combination of risk factors; excessive sweating and fast fatigue - in patients with obesity.

The obtained results suggest that $\mathrm{HF}, \mathrm{AH}$ and obesity both as separate factors, and on the whole worsen the course of the MI recovery period. Changes in cardiac hemodynamics in patients who had undergone MI with concomitant $\mathrm{HF}$ and with a combination of risk factors were accompanied by the eccentric hypertrophy onset, characterized by a combination of the LV cavities dilation with hypertrophy of its walls and the decreased contractility. The most significant LV hypertrophy was observed in MI patients with concomitant hypertension.

Significant increase of blood pressure levels according to the office measurement indices was observed in the groups of patients who suffered from MI with a combination of risk factors and in patients with concomitant $\mathrm{AH}$. Thus, in patients with $\mathrm{AH}$ there were frequent headaches and dizziness against the background of both SBP and DBP growth. The greatest exercise tolerance reduction according to the six-minute walk test was observed in the group of MI patients with a combination of cardiovascular events risk factors against the background of growing heart rate, blood pressure, LV remodeling indices and, consequently, increased ischemic changes in the LV myocardium.

\section{References:}

1. Nascimento B, Brant L, Moraes D, Ribeiro A. Global health and cardiovascular disease. Ukraiinskyi kardiolohichnyi zhurnal. 2016; 4:123-133. https://doi.org/:1136/heartjnl-2014-306026

2. Yermak OS, Kravchun PH, Ryndina NH, Rynchak PI. Copeptin, MRproADM and cardiac hemodynamyc indicators in patients with acute myocardial infarction depending on obesity occurrence. Bukovinian Medical Herald. 2016; 1(73):65-68. /Published in Ukraine/

3. van Riet EE, Hoes AW, Wagenaar KP, et al. Epidemiology of heart failure: the prevalence of heart failure and ventricular dysfunction in older adults over time. A systematic review. Eur J Heart Fail. 2016; 18:242-252. https://doi.org/:10.1002/ejhf.483.

4. Mishchenko LA. Zvyazok netradytsiynykh chynnykiv sertsevo-sudynnoho ryzyku z oznakamy aterosklerozu u khvorykh na hipertonichnu khvorobu. Arteryalnaya gipertenziya. 2011; 1(15):29-32. /Published in Ukraine/

5. Vakalyuk IP, Varunkiv NB. Pokaznyky dobovykh profiliv arterialnoho tysku u protsesi vidnovnoho likuvannya iz zastosuvannya valsakoru u khvorykh vysokoho sertsevo-sudynnoho ryzyku yaki perenesly infarkt miokarda. Hazeta Novosty medytsyny y farmatsyy. 2011; 10:365. /Published in Ukraine/

6. Moraes-Silva IC, Rodrigues B, Coelho-Junior HJ, Feriani DJ, Irigoyen MC. Myocardial Infarction and Exercise Training: Evidence from Basic Science. Exercise for Cardiovascular Disease Prevention and Treatment. Adv Exp Med Biol. 2017; 999:139-153. https://doi.org/:10.1007/978-981-10-4307-9_9.

7. Rossini R, Oltrona VL, Musumeci G, Filippi A, Pedretti R, Lettieri C,Buffoli F, et al. Italian Society 
of Invasive Cardiology (SICI-GISE); National Association of Hospital Cardiologists (ANMCO); Italian Association for Cardiovascular Prevention and Rehabilitation (GICR-IACPR); Italian Society of General Practitioner (SIMG). A multidisciplinary consensus document on follow-up strategies for patients treated with percutaneous coronary intervention. Catheter Cardiovasc Interv. 2015; 85:E129-39.

8. Malfatto G, Revera M, Branzi G, Ciambellotti F, Giglio A, Blengino S, Facchini M. A brief period of intensive cardiac rehabilitation improves global longitudinal strain and diastolic function after a first uncomplicated myocardial infarction. Acta Cardiologica 2017; 72(3):284-291. doi:10.1080/00015385. 2017.1305196.

9. Joyce E, Hoogslag GE, Leong DP, Debonnaire P, Katsanos S, Boden H, Schalij MJ, Marsan NA, Bax JJ, Delgado V. Association between left ventricular global longitudinal strain and adverse left ventricular dilatation after ST-segmentelevation myocardial infarction. Circ Cardiovasc Imaging. 2014; 7:74-81.

10. Susca, MG, Hodas R, Benedek T, Benedek I, Chitu M, Opincariu D, Rezus C. Impact of cardiac rehabilitation programs on left ventricular remodeling after acute myocardial infarction. Medicine. 2020; 99(16):e19759. doi:10.1097/md.0000000000019759.

\section{УДК 616-71+615.825+616.127-005.8+616.12-008.46 КЛІНІЧНІ ОСОБЛИВОСТІ \\ РЕАБІЛІТАЦІЙНОГО ПЕРІОДУ ПІСЛЯ ПЕРЕ- НЕСЕНОГО ІНФАРКТУ МІОКАРДУ ТА ДЕКО- МПЕНСОВАНОЇ СЕРЦЕВОЇ НЕДОСТАТНОСТІ 3 ОГЛЯДУ НА ФАКТОРИ СЕРЦЕВО- СУДИННОГО РИЗИКУ}

І.П. Вакалюк, Х.В. Левандовська, Н.Б. Тимочко

Івано-Франківський національний медичний університет, кафедра внутрішньої медицини №2 та

медсестринства,

м. Івано-Франківськ, Украӥна,

ORCID ID: 0000-0002-4430-6816,

ORCID ID: 0000-0003-3259-7940,

ORCID ID: 0000-0002-5319-5468,

e-mail: levandovska87@ukr.net

Резюме. Мета: провести аналіз клінічних особливостей періоду відновлення після інфаркту міокарда з урахуванням серцево-судинних факторів ризику.

Матеріали та методи. Обстежено 175 осіб 3 інфарктом міокарда та супутніми факторами ризику. Групи досліджень були однорідними за віком, статтю, тяжкістю захворювання, клінічними ознаками декомпенсації, що послужило основою для включення пацієнтів у дослідження.

Всім пацієнтам було проведено загальноклінічне обстеження (аналіз больового синдрому, анамнез, об'єктивне обстеження), клінічне та інструментальне (електрокардіографія, ехокардіоскопія, 6хвилинний тест ходьби) та лабораторні тести (ліпідо- грама, рівень лептину). Усі пацієнти були розділені на групи за наявністю факторів ризику.

Результати. Найважливішими факторами серцево-судинного ризику, що погіршують постінфарктний період, є вік, артеріальна гіпертензія, цукровий діабет, серцева недостатність, вроджені та набуті дефекти клапанів, ожиріння. У пацієнтів із поєднаною серцевою недостатністю, артеріальною гіпертензією, ожирінням клініка періоду відновлення після інфаркту міокарда характеризується суттєвим зниженням толерантності до фізичних навантажень (92,30\% пацієнтів).

Висновки. Зміни серцевої гемодинаміки у хворих, які перенесли інфаркт міокарда із супутньою серцевою недостатністю та 3 поєднанням факторів ризику, супроводжувалися початком ексцентричної гіпертрофії, що характеризується поєднанням розширення порожнин лівого шлуночка 3 гіпертрофією його стінок та зниженням його скоротливої здатності. Наявність декомпенсованої серцевої недостатності значно погіршує результативність шестихвилинного тесту на ходьбу.

Ключові слова: інфаркт міокарда, декомпенсована серцева недостатність, фактори ризику, період відновлення.

\section{УдК 616-71+615.825+616.127-005.8+616.12-008.46 КЛИНИЧЕСКИЕ ОСОБЕННОСТИ РЕАБИЛИТАЦИОННОГО ПЕРИОДА ПОСЛЕ ПЕРЕНЕСЕННОГО ИНФАРКТА МИОКАРДА И ДЕКОМПЕНСИРОВАННОЙ СЕРДЕЧНОЙ НЕ- ДОСТАТОЧНОСТИ С УЧЕТОМ ФАКТОРОВ СЕРДЕЧНО-СОСУДИСТОГО РИСКА}

\author{
И.П. Вакалюк, К.В. Левандовська, Н.Б. Тымочко
}

Ивано-Франковский нацииональный медицинский университет, кафедра внутренней медииинь №2 и медсестринства, г. Ивано-Франковск, Украина, ORCID ID: 0000-0002-4430-6816,

ORCID ID: 0000-0003-3259-7940,

ORCID ID: 0000-0002-5319-5468,

e-mail:levandovska87@ukr.net

Резюме. Цель: провести анализ клинических особенностей периода восстановления после инфаркта миокарда с учетом сердечно-сосудистых факторов риска.

Материалы и методы. Обследовано 175 человек с инфарктом миокарда и сопутствующими факторами риска. Группы исследований были однородными по возрасту, полу, тяжести заболевания, клиническим признакам декомпенсации, что послужило основой для включения пациентов в исследование.

Всем пациентам было проведено общеклиническое обследование (анализ болевого синдрома, анамнез, объективное обследование), клиническое и инструментальное (электрокардиография, эхокардиоскопия, 6-минутный тест ходьбы) и лабораторные тесты (липидограмма, уровень лептина). Все пациен- 
ты были разделены на группы по наличию факторов риска.

Результаты. Важнейшими факторами сердечно-сосудистого риска, ухудшающими постинфарктный период, являются возраст, артериальная гипертензия, сахарный диабет, сердечная недостаточность, врожденные и приобретенные дефекты клапанов, ожирение. У пациентов с сочетанной сердечной недостаточностью, артериальной гипертензией, ожирением клиника восстановительного периода после инфаркта миокарда характеризуется существенным снижением толерантности к физическим нагрузкам (92,30\% пациентов).
Выводы. Изменения сердечной гемодинамики у больных, перенесших инфаркт миокарда с сопутствующей сердечной недостаточностью и с сочетанием факторов риска, сопровождались началом эксцентрической гипертрофии, характеризующейся сочетанием расширения полостей левого желудочка с гипертрофией его стенок и снижением его сократительной способности. Наличие декомпенсированной сердечной недостаточности значительно ухудшает результативность шестиминутного теста на ходьбу.

Ключевые слова: инфаркт миокарда, декомпенсированная сердечная недостаточность, факторы риска, период восстановления.

Стаття надійшла в редакцію 22.03.2021 p. 